\title{
Survey of cadmium, lead, and arsenic in sesame from Iran
}

\author{
Niloofar Khoshbakht Fahim, Hamed Reza Beheshti, Somayeh Sadat Fakoor Janati and Javad Feizy ${ }^{*}$
}

\begin{abstract}
Background: Sesame is one of the most consumed oilseeds in human food in the whole world. In various forms, it is used for the preparation of foods, cookies, cakes, and so on. This study was applied for the determination of lead, cadmium, and arsenic in 80 samples of sesame purchased from supermarkets in Khorasan province, Iran.

Results: The results showed that arsenic is one of the trace elements in crops (edible plants) with an average concentration of $54 \mathrm{ng} \mathrm{g}^{-1}$, and three (3.75\%) samples were above the maximum tolerated level of $\mathrm{Pb}$ in Iran $\left(100 \mathrm{ng} \mathrm{g}^{-1}\right)$ regulations.

Conclusions: The results were obtained after complete digestion of these samples and determination using graphite furnace atomic absorption spectrometry and hydride generation atomic absorption spectrophotometry and indicate that $96.25 \%$ of the sesame samples could be suitable for human food.
\end{abstract}

Keywords: Sesame, Cadmium, Lead, Arsenic, AAS

\section{Background}

Sesame (Sesamum indicum L.) is one of the edible seeds in human foods in the whole world. Sesame is probably the most ancient oilseed cultivated in several countries such as India, Sudan, China, and Burma which are considered as the major producers $(60 \%$ of its total world production) [1]. It is widely used as food in the Iranian kitchen and food sector.

Lead and cadmium are known as toxic elements. Both metals cause adverse health effects in humans, and their widespread presence in the human environment comes from anthropogenic activities [2]. These elements are not natural substances in nutrition [3]. Cadmium ions are easily absorbed by vegetables and in animal-based food and are principally distributed in the liver and kidneys. The highest cadmium concentrations are found in rice, wheat, oyster, mussels, and the kidney cortex of animals [4]. Lead is a well-documented metal toxicant, exposure of which leads to many fatal diseases, including the dysfunction of renal blood and neurological systems [5]. The effect of lead is actually similar to cadmium [6]. Arsenic is a ubiquitous element, introduced to the environment from natural and anthropogenic sources [7]. It

\footnotetext{
*Correspondence: feizy.j@gmail.com

Testa Quality Control Laboratory, North-East Food Industrial Technology and Biotechnology Park, Mashhad 9176874185, Iran
}

is known to be one of the most toxic elements and has serious effects on plants, animals, and human health [8]. Because of the possible health risk, it is very important to control the level of these toxic elements in food, especially in products, which are known to have beneficial effects on health.

In the analysis of heavy metals in plant materials and food samples, atomic absorption spectrometry (GFAAS, FAAS) is reported most frequently [9]. Other techniques such as inductively coupled plasma mass spectrometry $[9,10]$, inductively coupled plasma atomic emission spectrometry [11], and electrochemical sensor TMFE [11] are also frequently employed. Procedures involving separation and preconcentration for the determination of cadmium using spectrometric techniques are reviewed by Ferreira et al. [12]. The aim of the presented work is to estimate the quantity of $\mathrm{Cd}, \mathrm{Pb}$, and As intake in sesame, especially those sold and consumed in the Khorasan province of Iran.

\section{Methods \\ Apparatus}

An Analytik Jena AG AAS ZEEnit 700 AAS (Jena, Germany) equipped with a hydride generation system (HS60) and graphite furnace (GF) with the Zeeman background corrector was used in the experiments. WinAAS 
Table 1 Parameters for working elements

\begin{tabular}{lccc}
\hline Analyte & Wavelength $(\mathbf{n m})$ & Lamp intensity $(\mathbf{m A})$ & Split $(\mathbf{n m})$ \\
\hline $\mathrm{Cd}$ & 228.8 & 3 & 1.2 \\
$\mathrm{~Pb}$ & 283.3 & 4 & 0.8 \\
\hline
\end{tabular}

software was used for data management. $\mathrm{Cd}$ and $\mathrm{Pb}$ were determined with a graphite furnace atomic absorption spectrophotometer (GFAAS). Arsenic was determined using a hydride generation atomic absorption spectrophotometer (HGAAS). The operating parameters for the working elements are given in Tables 1 and 2.

\section{Reagents and solutions}

All the analytical grade reagents were obtained from Merck (Darmstadt, Germany). Deionized double-distilled water was used throughout the experimental work. Laboratory glassware were kept overnight in 10\% $(v / v)$ nitric acid. Before use, the glassware were rinsed with deionized water and dried in a dust-free environment. The phosphate-matrix modifier solution (Merck) was added to the samples, and standards were prepared by diluting $1 \mathrm{~mL}$ of phosphate modifier stock solution $\left(\mathrm{NH}_{4} \mathrm{H}_{2} \mathrm{PO}_{4}\right.$ $100 \pm 2 \mathrm{~g} \mathrm{~L}^{-1}$ in $\mathrm{H}_{2} \mathrm{O}$ ) to $10 \mathrm{~mL}$, resulting in a final concentration of $2,500 \mathrm{mg} \mathrm{L}^{-1}$ phosphate. The sesame samples investigated in this study were locally available brands, collected in supermarkets from Khorasan province, Iran. Samples were dried; then, dried samples were homogenized using an agate homogenizer and stored in polyethylene bottles until analysis.

\section{Results and discussion}

In this work, $\mathrm{Cd}$ and $\mathrm{Pb}$ were analyzed by GFAAS and As with HGAAS. Various sources contribute to the metal composition of sesame. The main sources of heavy metals to plants are their growth media, like nutrient solution and soils $[13,14]$. The analytical characteristics of the atomic absorption spectrometry (AAS) method are shown in Table 3.

Accuracy was examined using the determination of the recoveries of $\mathrm{Cd}, \mathrm{Pb}$, and As. The recovery study was performed by comparing the concentration in the sesame-spiked samples to the respective non-extract standards $(\mathrm{Cd}, \mathrm{Pb}$, and $\mathrm{As}$ in solution). The recoveries of

Table 2 Analytical parameters for arsenic determination by HGAAS

\begin{tabular}{|c|c|}
\hline Parameter & Result \\
\hline Wavelength & $193.7 \mathrm{~nm}$ \\
\hline Acid volume & $10 \mathrm{~mL}\left(3 \mathrm{~mol} \mathrm{I} \mathrm{I}^{-1} \mathrm{HCl}\right)$ \\
\hline Reductant & $10 \mathrm{~g} \mathrm{~L}^{-1} \mathrm{NaBH}_{4}$ \\
\hline Reaction time & $20 \mathrm{~s}$ \\
\hline Read time & $50 \mathrm{~s}$ \\
\hline
\end{tabular}

Table 3 Analytical characteristics of the AAS method

\begin{tabular}{lcccc}
\hline Analyte & $\begin{array}{c}\text { Limit of } \\
\text { detection } \\
(\mathbf{n g} / \mathbf{m L})\end{array}$ & $\begin{array}{c}\text { Limit of } \\
\text { quantification } \\
(\mathbf{n g} / \mathbf{m L})\end{array}$ & $\begin{array}{c}\text { Repeatability } \\
(\% R S D, \boldsymbol{n}=\mathbf{7})\end{array}$ & $\begin{array}{c}\text { Recovery } \\
(\mathbf{\pm S D}, \boldsymbol{n}=\mathbf{7})\end{array}$ \\
\hline $\mathrm{Cd}$ & 0.34 & 1.1 & 1.10 & $98.2( \pm 2.3)$ \\
$\mathrm{Pb}$ & 0.66 & 2.1 & 0.42 & $97.6( \pm 1.6)$ \\
$\mathrm{As}$ & 0.23 & 0.7 & 3.63 & $98.4( \pm 2.5)$ \\
\hline
\end{tabular}

$\mathrm{Cd}, \mathrm{Pb}$, and $\mathrm{As}$ from samples spiked at 10 and $50 \mathrm{ng} \mathrm{g}^{-1}$ for $\mathrm{Cd}$ and $\mathrm{Pb}$, respectively, and $2 \mathrm{ng} \mathrm{g}^{-1}$ for As were quite good (Table 3). Relative standard deviations for within-laboratory repeatability $\left(\operatorname{RSD}_{\mathrm{r}} n=7\right)$ range from 1.6 to 2.6. The recoveries of the mineral elements were in the order of $97.6 \%$ to $98.4 \%$. These results confirm the validity of the method for the determination of the investigated metals.

The relative standard deviations were $13.12 \%, 31.90 \%$, and $26.21 \%$ for $\mathrm{Cd}, \mathrm{Pb}$, and As, respectively (Table 4). $\mathrm{Cd}, \mathrm{Pb}$, and As concentrations were compared with upper limits (100 $\mathrm{ng} \mathrm{g}^{-1}$ for $\mathrm{Cd}, \mathrm{Pb}$, and $\mathrm{As}$ ) that was approved by the Iranian National Standard [15]. The results showed that As was the most abundant of the trace elements in sesame with an average concentration of $54 \mathrm{ng} \mathrm{g}^{-1}$, and three (3.75\%) samples were above the maximum tolerated level of $\mathrm{Pb}$ in Iran $\left(100 \mathrm{ng} \mathrm{g}^{-1}\right)$ regulations.

\section{Experimental}

\section{Digestion procedures}

For digestion with wet ashing, $5 \mathrm{~g}$ of sesame samples was used (the particle sizes after grinding were below $0.3 \mathrm{~mm}$ ). Wet digestion of the samples was performed by using mixtures of two acids, namely, $\mathrm{HNO}_{3}-\mathrm{HCl}$. Thirty milliliters of concentrated $\mathrm{HNO}_{3}$ was used for a 5.0-g sample. For this procedure, the temperature was maintained at $120^{\circ} \mathrm{C}$ during digestion of the sample with acid mixtures on the hot plate. The sample was gently boiled until 3 to $6 \mathrm{~mL}$ of digest remains. Then, $25 \mathrm{~mL}$ of concentrated $\mathrm{HCl}$ was added. The heat was increased and the sample boiled until 10 to $15 \mathrm{~mL}$ of volume remains. After cooling, the residue was filtered through blue band filter paper. Then, the sample was diluted to $50 \mathrm{~mL}$ with distilled water. The blank digestions were also carried out in the same way [16].

Table 4 Metal concentration (ng/g, dry weight) of sesame samples

\begin{tabular}{lcc}
\hline Analyte & Average $\left( \pm \mathbf{S D}^{\mathbf{a}}\right)$ & Range \\
\hline $\mathrm{Cd}$ & $15.7( \pm 13.12)$ & 0.45 to 62 \\
$\mathrm{~Pb}$ & $51.6( \pm 31.9)$ & 6 to 123 \\
As & $54( \pm 26.21)$ & 13 to 99 \\
\hline${ }^{\mathrm{a} S \mathrm{SD}, \text { standard deviation. }}$ &
\end{tabular}




\section{Calibration curves}

Three external standard curves were constructed using reference standard to determine the metal $(\mathrm{Cd}, \mathrm{Pb}$, and As) content in all samples. Calibration curves were determined using five or six different concentrations. The squares of correlation coefficients $\left(r^{2}\right)$ were 0.989, 0.996, and 0.996 for $\mathrm{Cd}, \mathrm{Pb}$, and As, respectively.

\section{Conclusions}

In this study, 80 sesame samples from the Khorasan province of Iran were analyzed for three elements using furnace $(\mathrm{Cd}$ and $\mathrm{Pb})$ and hydride generation (As) atomic absorption spectrophotometry and an acid digestion method. The acid digestion system in the sesame samples provides a simple and effective method of the sample digestion. This study is expected to provide an important insight into the disparity of the mineral element concentrations in different sesame samples. It is shown that $\mathrm{Cd}$ was detected in $76.25 \%$ with a mean value of $15.7 \mathrm{ng} \mathrm{g}^{-1}$. $\mathrm{Pb}$ and $\mathrm{As}$ were detected in all samples with a mean value of 51.6 and $54 \mathrm{ng} \mathrm{g}^{-1}$, respectively. Maximum contents of $\mathrm{Cd}, \mathrm{Pb}$, and $\mathrm{As}$ in the all samples were found as 62, 123, and $99 \mathrm{ng} \mathrm{g}^{-1}$, respectively. Therefore, there is a need to routinely monitor these as a food quality control measure. Additional investigations, currently ongoing with our samples, will provide further information on this potentially useful taxonomic tool.

\section{Competing interests}

The authors declare that they have no competing interests.

\section{Authors' contributions}

JF conducted all the experiments mentioned in the manuscript. NKF and HRB participated in the design of the study and in drafting the manuscript and performed the statistical analysis. SSFJ participated in its design and coordination. All authors read and approved the final manuscript.

\section{Acknowledgment}

The authors thank the Testa Quality Control Laboratory (TQCL) for financial supports.

Received: 16 September 2012 Accepted: 27 December 2012 Published: 11 February 2013

\section{References}

1. Abou-Gharbia HA, Shehata AAY, Shahidi F (2000) Effect of processing on oxidative stability and lipid classes of sesame oil. Food Res Int 33:331-340

2. Viñas P, Pardo-Martinez M, Hernandez-Cordoba M (2000) Rapid determination of selenium, lead and cadmium in baby food samples using electrothermal atomic absorption spectrometry and slurry atomization. Anal Chim Acta 412:121-130

3. Kristl J, Veber M, Slekovec M (2003) The contents of Cu, Mn, Zn, Cd, Cr and $\mathrm{Pb}$ at different stages of the winemaking process. Acta Chimica Slovenica 50:123-136

4. Gama EM, da Silva LA, Lemos VA (2006) Preconcentration system for cadmium and lead determination in environmental samples using polyurethane foam/Me-BTANC. J Hazard Mater 136:757-762

5. Mittal SK, Goyal S (1995) Studies on suspended particulate matter in ambient air of an industrial area. Indian J Environmental Protection 15:839-844

6. Rudy M (2009) The analysis of correlations between the age and the level of bioaccumulation of heavy metals in tissues and the chemical composition of sheep meat from the region in SE Poland. Food Chem Toxicol 47:1117-1122

7. Sloth JJ, Julshamn K, Lundebye AK (2005) Total arsenic and inorganic arsenic content in Norwegian fish feed products. Aquacult Nutr 11:61-66

8. Munoz E, Palmero S (2000) Analysis and speciation of arsenic by stripping potentiometry: a review. Talanta 65:613-620

9. Sołtyk K, Fijałek Z (2000) Inductively-coupled plasma mass spectrometric (ICP-MS) and graphite-furnace atomic absorption spectrometric (GF-AAS) determinations of arsenic, cadmium and lead impurities in medical herbal raw materials. Anal Chem 45:879-886

10. Łozak A, Sołtyk K, Ostapczuk P, Fijałek Z (2002) Determination of selected trace elements in herbs and their infusions. Sci Total Environ 289:33-40

11. Palchetti I, Mascini M, Minunni M, Bilia AR, Vincieri FF (2003) Disposable electrochemical sensor for rapid determination heavy metals in herbal drugs. PH Bio Anal 32:251-256

12. Ferreira S, de Andrade Jailson B, Korn Maria das Garcas A, Pereira M, Lemos V, dos Santos W, Rodrigues F, Souza A, Ferreira H, da Silva E (2007) Review of procedures involving separation and preconcentration for the determination of cadmium using spectrometric techniques. J Hazard Mater 145:358-367

13. Tüzen M (2003) Determination of heavy metals in soil, mushroom and plant samples by atomic absorption spectrometry. Microchem J 74(3):289-297

14. Tüzen M (2003) Determination of heavy metals in fish samples of the middle Black Sea (Turkey) by graphite furnace atomic absorption spectrometry. Food Chem 80:119-123

15. Institute of Standards and Industrial Research of Iran (2008) Sesame seeds specification and test methods. 2nd revision, No. 323. ISIRI, Tehran

16. Association of Analytical Chemists (2005) Tin in canned foods atomic absorption spectrophotometric method. AOAC Official Method 985.16 AOAC International, Gaithersburg

doi:10.1186/2228-5547-4-10

Cite this article as: Fahim et al: Survey of cadmium, lead, and arsenic in sesame from Iran. International Journal of Industrial Chemistry 2013 4:10.

\section{Submit your manuscript to a SpringerOpen ${ }^{\odot}$ journal and benefit from:}

- Convenient online submission

- Rigorous peer review

- Immediate publication on acceptance

- Open access: articles freely available online

- High visibility within the field

- Retaining the copyright to your article

Submit your next manuscript at $>$ springeropen.com 